\title{
IMPLEMENTASI PENDEKATAN SAINTIFIK DENGAN METODE ROLE PLAYING YANG DIMODIFIKASI PERMAINAN DOMINO PADA PEMBELAJARAN KURIKULUM 2013
}

\author{
Budi Sasomo \\ UNISDA Lamongan \\ sasomo77@gmail.com
}

Moh. Arif Hidayat

SMPN 3 Ngadirojo

\begin{abstract}
The purpose of this paper was to examine the mathematics achievement of students who are subject to a scientific approach using role playing method and dominoes game. Based on the hypothesis testing using anava one way concluded with a scientific approach using role playing method and dominoes game got better achievement than classes that are subject to direct learning instruction. Thus the scientific approach using role playing method and dominoes game could be an alternative to learning mathematics for teacher who taught in the schools using the curriculum of 2013.
\end{abstract}

Keywords : scientific approach, role playing, dominoes game

\begin{abstract}
ABSTRAK. Tujuan dari penulisan ini adalah untuk mengetahui prestasi belajar matematika siswa yang dikenai pembelajaran pendekatan saintifik dengan metode role playing yang dimodifikasi permainan domino. Berdasarkan hasil perhitungan uji hipotesis dengan menggunakan anava 1 jalan didapat kesimpulan pembelajaran pendekatan saintifik dengan metode role playingyang dimodifikasi permainan domino memperoleh prestasi belajar yang lebih baik daripada kelas yang dikenai pembelajaran pendekatan saintifik dengan metode role playing. Kelas yang dikenai pembelajaran pendekatan saintifik dengan metode role playing memperoleh prestasi belajar yag lebih baik daripada kelas yang dikenai pembelajaran langsung. Dengan demikian pembelajaran pendekatan saintifik dengan metode role playingdan permainan domino dapat menjadi alternatif pembelajaran untuk guru matematika yang mengajar di sekolah yang menggunakan kurikulum 2013.
\end{abstract}

Kata kunci : pendekatan saintifik, role playing, dan permainan domino

\section{PENDAHULUAN}

Pendidikan merupakan wadah dari semua pembelajaran yang dilaksanakan oleh pendidik kepada peserta didik dalam waktu yang ditentukan. Pembelajaran bisa diartikan sebuah tindak yang sengaja dilakukan dengan tujuan meningkatkan nilai perilaku individu dalam suatu keadaan tertentu menjadi 
keadaan yang lebih baik. Jika pembelajaran berlangsung dalam sebuah pendidikan maka membutuhkan suatu sistem pendidikan yang akan mengatur atau sebagi pedoman dalam pelaksanaannya. Hal tersebut senada dengan pengertian dari kurikulum. Pembelajaran yang perlu diperhatikan adalah pembelajaran yang menekankan peserta didik untuk berpikir kritis dan kreatif.

Pada kenyataannya hasil hasil UN pada tahun 2015 lalu menunjukkan daya serap siswa SMP N 3 Ngadirojo pada barisan bilangan dan deret rendah baik dalam provinsi maupun secara nasional. Peran pendidik yang sangat sentral sehingga pembelajaran sepenuhnya dalam penguasaannya. Meskipun pembelajaran kooperatif sering kali ditawarkan menjadi solusi dari permasalahan tersebut namun hal itu tidak menjadi tidak menjadikan peserta didik mencapai hasil pembelajaran yang lebih baik. Peserta didik yang pandai cukup berperan dalam pembelajaran kooperatif sehingga dalam menyampaikan hasil diskusi materi kurang terlihat kemampuan individu dari peserta didik. Padahal pembelajaran yang baik mempu menghasilkan peserta didik yang kreatif inovatif dan mampu mempelajari pengetahuan dalam setiap pembelajaran yang berlangsung.

Pembelajaran yang menitik beratkan pada pandangan konstruktivisme merupakan pembelajaran yang baik untuk diterapkan.Hal ini sejalan dengan Kurikulum 2013 berbasis scientific yang sedang dikembangkan saat ini (Kemendikbud, 2013). Kurikulum 2013 dengan menggunakan pendekatan ilmiah yang mengutamakan pada dimensi pedagogik modern dalam pembelajaran. Pendekatan ilmiah (scientifi capproach) yang diharapkan menjadi dasar utama untuk meningkatkan kearah positif dari sikap,keterampilan dan pengetahuan peserta didik. Kurikulum 2013 yang akhir-akhir ini sedang hangat diperbincangkan diharapkan mampu menutupi segala kekurangan dari kurikulum yang sebelumnya dan menjadikan semangat baru untuk menjadikan pendidikan di Indonesia menjadi lebih baik lagi.

Kurikulum 2013 yang menganggap semua mata pelajaran harus mempunyai peran terhadap pembentukan 3 aspek peserta didik yanitu aspek afektif atau sikap, aspek psikomotorik atau ketrampilan dan aspek kognitif atau pengetahuan,hal ini sesuai dengan pendapat Sinambela (2013). Ketrampilan yang menjadi modal dasar untuk menemukan dan mengembangkan konsep serta menumbuhkan dan mengembangkan aspek sikap dan pengetahuan. Ketrampilan 
dari peserta didik mampu mejadikan pembelajaran lebih baik karena ketrampilan menuntut peserta didik untuk lebih kreatif, inovatif dalam menggali pengetahuan yang lebih tinggi dengan waktu yang relatif singkat.

Setiap pembelajaran pasti diharapkan menghasilkan peserta didik yang lebih baik, hal ini bisa dilihat dari penilai terhadap ketiga aspek tersebut. Adapun aspek kognitif dapat dilihat dari pengetahuan, pemahaman dan keterampilan intelektual peserta didik. Aspek afektif bercermin pada sikap dan emosi peserta didik dalam pembelajaran. Aspek yang ketiga yaitu aspek psikomotor tentunya berhubungan dengan keterampilan individu dari peserta didik tersebut. Untuk mengukur pencapain dari ketiga aspek tersebut tentunya bukan hal yang mudah. Perlu adanya pembelajaran yang bisa mengeksplorasi kemampuan individu secara baik. Pembelajaran dengan pendekatan saintifik yang dikombinasikan dengan metode role playing mampu mempermudah penilaian individu dan prestasi dari peserta didik menjadi lebih baik, hal ini senada dengan Sasomo (2015).

Pendekatan saintifik adalah pendekatan yang berbasis pada kenyataan di lapangan atau fenomena yang dapat dijelaskan dengan logika atau penalaran tertentubukan berdasarkan asumsi atau khayalan belaka (Kemendikbud, 2013). Pendekatan saintifik dapat diartikan pendekatan yang berbasis pada fakta untuk memperoleh pengetahuan baru secara terampil melalui proses pembelajaran dengan mengikuti tahapan-tahapan secara terperinci, hal ini sependapat dengan Sasomo (2015). Adapun tahapan-tahapan tersebut yaitu mengidentifikasi masalah, merumuskan masalah dari hasil identifikasi, menalar dengan teori yang telah dipelajari, mencoba merumuskan hipotesis, menarik kesimpulan dan mengkomunikasikan yang terjadi dari pengetahuan yang dipelajari. Pada pembelajaran saintifik kemampuan individu sangat sentral dalam hal ini ditunjukan peserta didik harus terampil dalam melalui tahapan-tahapan pendekatan saintifik.

Dengan demikian peserta didik mengambil peranan penuh dalam pembelajaran, tentuya dengan kontrol dari seorang guru. Peran utama adalah peserta didik dan akan lebih menarik lagi peran tersebut telah disusun oleh guru dalam sebuah skenario yang nantinya akan dimaikan oleh peserta didik, yang 
demikian itu sesuai pendapat. Seperti halnya diungkapkan oleh Baroro (2011) metode role playing dapat meningkatkan keterampilan dalam belajar sehingga dapat meningkatkan hasil belajar. Dengan demikian kombinasi antara pendekatan saintifik dengan metode role playing untuk mempermudah penilaian individu peserta didik, hal ini sepaham dengan pendapatnya Sasomo (2015). Peran yang sangat sentral dari peserta didik adalah rahasia dari keberhasilan pembelajaran ini.

Peran akan menjadi lebih mengasyikan lagi jika menambahkan permainan domino dalam pembelajaran ini. Permainan domino merupakan kegiatan menggunakan tumpukan kartu yang dimainkan oleh beberapa orang untuk memperoleh informasi dari permasalahan tertentu, yang demikian itu diungkapkan oleh Sasomo (2014). Selain menyenangkan permainan ini juga memperjelas peran dari masing-masing individu dan akan lebih mempermudah guru dalam menilai peserta didik secara individu. Berdasarkan hasil penelitian Sasomo (2014) permainan domino ini membantu siswa menumbuhkan semangat belajarnya sehingga prestasi belajarnya menjadi lebih baik.

Berdasarkan pemaparan di atas munculah semangat peneliti untuk menerapkan pembelajaran menggunakan pendekatan saintifk dengan metode role playing yang dimodifikasi dengan permainan domino pada pembelajaran kurikulum 2013. Pembelajaran ini diharapkan mampu menghasilkan pembelajaran yang lebih baik dengan peserta didik memperoleh prestasi belajar yang lebih baik pula. Dengan demikian peserta didik juga mampu menyelesaikan masalah yang dihadapinya dengan menyelesaikan tahapan yang harus dilaluinya dengan sabar.

\section{METODE PENELITIAN}

Metode penelitian yang digunakan adalah metode eksperimen semu (quasi eksperimental research). Perlakuan terhadap sampel dengan melaksanakan pembelajaran pada mata pelajaran barisan bilangan dan deret menggunakan pendekatan saintifk dengan metode role playingyang dimodifikasi dengan permainan domino, pendekatan saintifk dengan metode role playing dan pembelajaran langsung.

Penelitian ini dilaksanakan pada semester ganjil tahun pelajaran 2015/2016 
dengan jenis penelitian eksperimental semu. Populasi dalam penelitian ini adalah seluruh siswa semester ganjil kelas IX SMP N 3 Ngadirojo. Sampel yang digunakan adalah 3 kelas dari 6 kelas padaSMP N 3 Ngadirojo. Dalam penelitian ini dua kelas berfungsi sebagai kelas eksperimen dan kelas yang satunya berfungsi sebagai kelas kontrol.

Penelitian terdapat dua variabel bebas dan satu variabel terikat. Pendekatan saintifik dengan metode role playing yang dimodifikasi dengan permainan domino sebagai variabel bebas sedangkan prestasi belajar sebagai variabel terikat. Untuk mengumpulkan data digunakan metode dokumentasi dan metode tes. Metode dokumentasi digunakan untuk memperoleh data kemampuan awal berupa nilai mata pelajaran matematika dari hasil ujian akhir semester. Metode tes digunakan untuk mengumpulkan data prestasi belajar siswa. Adapun teknik analisis data yang digunakan untuk menguji hipotesis dalam penelitian ini adalah analisis variansi dengan satu jalan.

\section{HASIL DAN PEMBAHASAN}

Hasil penelitian yang didapatkan dari 2 kelas berupa nilai hasil belajar dari mata pelajaran matematika pada materi barisan dan deret aritmetika. Nilai tersebut kemudian dianalis menggunakan analisis variansi satu jalan sehingga didapat perhitunganujihipotesispenelitian seperti pada Tabel 1.

Tabel 1. Rangkuman hasil uji analisis variansi satu jalan

\begin{tabular}{|c|c|c|c|}
\hline & $\begin{array}{c}\text { Data Kelas } \\
\text { Eksperimen I }\end{array}$ & $\begin{array}{c}\text { Data Kelas } \\
\text { Eksperimen II }\end{array}$ & $\begin{array}{l}\text { Data Kelas } \\
\text { kontrol }\end{array}$ \\
\hline Rata-rata & 75,00 & 70,00 & 65,83 \\
\hline Banyaknya sampel & 25,00 & 26,00 & 24,00 \\
\hline $\mathbf{F}_{\text {observasi }}$ & \multicolumn{3}{|c|}{8,2059} \\
\hline $\mathbf{F}_{\text {tabel }}$ & \multicolumn{3}{|c|}{3,1239} \\
\hline
\end{tabular}

Data kelas eksperimen I menunjukkan hasil belajar untuk kelas yang dikenai pembelajaran pendekatan saintifik dengan metode role playing yang dimodifikasi dengan permainan domino. Data kelas eksperimen II menunjukkan hasil belajar untuk kelas yang dikenai pembelajaran pendekatan saintifik dengan 
metode role playing. Berdasarkan tabel 1 , menunjukan nilai $\mathrm{F}_{\mathrm{obs}}$ lebih besar daripada nilai $\mathrm{F}_{\text {tabel. }}$. Hal ini berarti terdapat perbedaan prestasi belajar antara kelas yang dikenai pendekatan saintifik dengan metode role playing yang dimodifikasi dengan permainan domino dan kelas yang dikenai pembelajaran pendekatan saintifik dengan metode role playing serta pembelajaran langsung.

Oleh karena terdapat perbedaan maka dengan melihat nilai dari rata-rata masing kelas didapat kesimpulan penelitian kelas eksperimen I dengan nilai ratarata 75,00 lebih baik daripada kelas eksperimen II dengan nilai 70,00 dan kelas kontrol dengan nilai 65,83. Hal tersebut berarti prestasi belajar siswa pada kelas yang dikenai pendekatan saintifik dengan metode role playing yang dimodifikasi dengan permainan domino lebih baik daripada kelas yang dikenai pembelajaran pendekatan saintifik dengan metode role playing dan pembelajaran langsung. Nilai rata-rata kelas eksperimen II yaitu 70,00 lebih baik daripada nilai rata-rata kelas kontrol. Hal tersebut menunjukkan prestasi belajar siswa pada kelas yang dikenai pendekatan saintifik dengan metode role playing lebih baik daripada kelas yang dikenai pembelajaran langsung.

Pembelajaran dengan pendekatan saintifik yang menitikberatkan pada realita di lapangan bukan hanya khayalan semata mampu membawa kondisi pembelajaran menjadi lebih menyenangkan. Pada beberapa penelitian juga telah membuktikan bahwa pendekatan saintifik dapat meningkatkan hasil belajar siswa, seperti yang telah dikemukan oleh Efriana (2014)Selain itu pendekatan saintifik mendorong siswa untuk lebih aktif dalam pembelajaran sehingga dapat mengeksplorasi segala pengetahuan untuk menemukan fakta dari suatu kejadian.

Pembelajaran saintifik dengan metode role playing merupakan pembelajaran yang menuntut peran siswa dalam pembelajaran menjadi yang paling dominan. Peran siswa yaitu menemukan dan menyelesaikan masalah berdasarkan kenyataan yang bisa dijelaskan dengan logika. Pada penelitian ini ketrampilan pemecahan masalah dengan pembelajaran saintifik dengan metode role playing lebih baik daripada pembelajaran langsung, hal ini sesuai dengan pendapatnya Uno (2011: 28). Pembelajaran ini juga menjadi solusi alternatif pada penerapan kurikulum 2013. Hal ini disebabkan pembelajaran ini mempermudah 
guru dalam menilai siswa pada saat pembelajaran berlangsung di ruang kelas, seperti yang dipaparkan oleh Sasomo (2015).

Permainan domino yang disisipkan pada pembelajaran ini menjadi lebih menarik minat belajar siswa. Antusias siswa dalam mengikuti pembelajaran dan permainan mempengaruhi hasil belajar siswa, hal ini senada dengan Utomo (2014). Dalam permainan domino ini selain menyenangkan juga membantu dalam penyelesaian masalah. Jika ada siswa yang tidak bisa atau salah dalam menyelesaikan masalah akan dibantu atau dikoreksi oleh teman sekelasnya sehingga kerjasama dalam pembelajaran terwujud dengan baik. Akibatnya hasil belajar siswa menjadi lebih baik, hal ini sependapat dengan Kasiyar (2011).

Di samping hasil belajar yang menjadi lebih baik ada hal lain yang merubah siswa menjadi kearah positif yaitu motivasi belajar siswa, hal ini senada dengan pendapatnya Amalia (2014). Jika motivasi tetap terjaga dengan baik maka semngat belajar akan tetap terjaga, akibatnya prestasi belajar menjadi lebih baik lagi. Permainan domino sangat membantu dalam pembelajaran ini baik dilihat dari antusias siswa, motivasi dan kerjasama antar siswa dalam satu kelas, seperti yang dikemukakan oleh Utomo (2014). Dengan demikian pembelajaran saintifik dengan metode role playing yang dimodifikasi permainan domino sangatlah membantu guru baik dalam pembelajaran maupun penilaian siswa.

Kurikulum 2013 yang menuntut guru menilai 3 aspek penilaian. Aspek kognitif dapat dilihat dalam pemecahan masalah yang dihadapi. Aspek afektif dapat dilihat pada proses pembelajaran atau pada proses metode role playing. Aspek psikomotor sangat menonjol pada permainan domino yang dituntut terampil memecahkan masalah dan mejalankan permainan. Penilaian dilakukan untuk mengukur ketercapaian pembelajaran. Adapun teknik maupun alat yang digunakan untuk penilaian terdapat beragam jenisnya, hal ini sependapat dengan Sujawanta (2012). Hasil penilaian pembelajaran digunakan guru untuk menganalisis kegiatan pembelajaran yang kemudian digunakan dasar pengambilan keputusan untuk pembelajaran berikutnya. 


\section{SIMPULAN DAN SARAN}

Berdasarkan analisis data dari penelitian yang dilakukan, dapat disimpulkan bahwa kelas yang dikenai pembelajaran pendekatan saintifik dengan metode role playing yang dimodifikasi dengan permainan domino memperoleh prestasi belajar yag lebih baik daripada kelas yang dikenai pembelajaran pendekatan saintifik dengan metode role playing dan metode ceramah atau pembelajaran langsung. Hal ini ditunjukkan dengan nilai rata-rata pada kelas yang dikenai pembelajaran pendekatan saintifik dengan metode role playing yang dimodifikasi dengan permainan domino lebih baik daripada kelas yang dikenai pembelajaran pendekatan saintifik dengan metode role playing dan pembelajaran langsung. kelas yang dikenai pembelajaran pendekatan saintifik dengan metode role playing lebih baik daripada pembelajaran langsung. Pada proses pembelajaran yang berlangsung guru atau dosen sangat terbantu dengan penerapan pembelajaran pendekatan saintifik dengan metode role playing yang dimodifikasi dengan permainan domino. Hal itu disebabkan peserta didik dituntut untuk menunjukkan kemampuan secara individu pada memerankan pemain domino.

Berdasarkan hasil penelitian yang telah dilakukan maka hal ini menjadi alternatif baru untuk pelaksanaan pembelajaran yang menggunakan kurikulum 2013 dengan menggunakan pendekatan saintifik dengan metode role playing yang dimodifikasi dengan permainan domino. Bagi pembaca disarankan menggunakan pendekatan saintifik dengan metode role playing yang dimodifikasi dengan permainan domino pada materi barisan dan deret. Bagi peneliti lain, hasil pada penelitian ini dapat dijadikan masukan untuk melakukan penelitian pada materi yang sama dan sebaiknya melakukan penelitian dengan pendekatan saintifik dengan metode role playing yang dimodifikasi dengan permainan domino ditinjau dari ketrampilan belajar siswa.

\section{DAFTAR PUSTAKA}

Amalina, E. N., Penerapan Metode Permainan dengan Media Kartu Domino dalam Pembelajaran Matematika untuk Meningkatkan Motivasi dan Hasil Belajar Siswa : Penelitian Tindakan Kelas di Kelas V SDN Cisalasih 
Semester II Tahun Ajaran 2013/ 2014 Kecamatan Lembang Kabupaten

Bandung Barat, Tesis, Universitas Pendidikan Indonesia, 2014.

Baroroh, K., Upaya Meningkatkan Nilai-Nilai Karakter Peserta Penerapan Metode Role Playing, Jurnal Ekonomi \& Pendidikan, 8(2) (2011).

Efriana, F., Penerapan Pendekatan Scientific untuk Meningkatkan Hasil Belajar Siswa Kelas VII MTSN Palu Barat pada Materi Keliling dan Luas Daerah Layang-Layang, Jurnal Elektronik Pendidikan Matematika, 1(2) (2014).

Esti, $\mathrm{T}$ dan Nursalim, Penerapan Latihan Asertif untuk Meningkatkan Keterampilan Komunikasi Interpersonal Siswa, Jurnal Psikologi, 2010, 118.

Kasiyar, Penerapan Pembelajaran Kooperatif Teams Games Turnamen (TGT) Berbantuan Media Kartu Domino untuk Meningkatkan Hasil Belajar Materi Akar Pangkat Tiga pada Siswa Kelas VI SDN Sumbergondo 01 Kota Batu, Prosiding ISBN: 978-602-1150-17-7, 2011.

Mendikbud, Pengembangan Kurikulum 2013, Sosialisasi Kurikulum 2013, Kemdikbud, 2013.

Sasomo, B., Eksperimentasi Model Pembelajaran Group Investigation (GI) yang Dimodifikasi pada Materi Bangun Ruang Sisi Datar Ditinjau dari Kemandirian Belajar Siswa Kelas VIII SMP Negeri Se-kabupaten Pacitan Tahun Pelajaran 2013/2014, Tesis, PPS UNS Surakarta, 2014.

Sasomo, B., Pendekatan Saintifik dengan Metode Role Playing Mempermudah Penilaian Individu Peserta Didik, Inspiramatika, 1(1) (2015).

Sasomo, B., Implementasi Pendekatan Saintifik dengan Metode Role Playing Mempermudah Penilaian Individu Peserta Didik, Jurnal Penelitian Pendidikan, 7(2) (2015), 1125-1187.

Sinambela, P. N. J. M., Kurikulum 2013 dan Implementasinya dalam Pembelajaran, Generasi Kampus, 6(2) (2013).

Sujarwanta, A., Mengkondisikan Pembelajaran IPA dengan Pendekatan Saintifik (Natural Science Learning Conditional with Saintific Approach), Jurnal Nuansa Kependidikan, 16(1) (2012). 
Uno, H. B., Model Pembelajaran Menciptakan Proses Belajar Mengajar yang Kreatif dan Efektif, PT Bumi Aksara, Jakarta, 2011.

Utomo, T. R. W., Johan, A., dan Kurniasari, I., Penerapan Metode Ekspositori Berbantuan Kartu Domino pada Pelajaran Matematika Materi Operasi Bilangan Bulat Kelas V SDN Sawahan IX/348 Surabaya, Jurnal Ilmiah Pendidikan Matematika, 3(1) (2014). 